\title{
APONTAMENTOS INICIAIS SOBRE A FORÇA GRAVITACIONAL DA JURISPRUDÊNCIA NO NOVO CÓDIGO DE PROCESSO CIVIL
}

\author{
Orlando Luiz Zanon Junior* \\ Fernando Vieira Luiz**
}

SUMÁRIO: Introdução; 2 Conceito operacional de jurisprudência; 3 Critérios de aplicabilidade no cenário brasileiro; 4 Conclusões; Referências.

RESUMO: O objetivo (ou referente) do presente texto é tratar da força gravitacional dos precedentes jurisprudenciais como elementos de determinação na tomada de decisões judiciais e, também, estabelecer alguns critérios quanto à sua incidência no contexto brasileiro, mormente considerando o Novo Código de Processo Civil (NCPC). A motivação para tratar deste assunto decorre do notável aumento da importância das decisões dos tribunais, notadamente os superiores, como argumentos persuasivos para formação da convicção judicial no cenário brasileiro. As conclusões foram no sentido de que a Jurisprudência é uma Fonte Jurídica de hierarquia decisiva no cenário jurídico brasileiro, posicionada logo abaixo dos Textos Normativos e dos Princípios Jurídicos, cuja relevância reside não no sentido do julgado (dispositivo), mas sim na apresentação dos argumentos pertinentes para resolução de casos similares (fundamentação estruturada), de modo a otimizar o lançamento de decisões judiciais, aumentar a coerência do Ordenamento Jurídico e preservar a história institucional do Direito. Também restou esclarecido que o NCPC conferiu um tratamento especial à força gravitacional da Jurisprudência no cenário brasileiro, de modo a alterar o funcionamento do sistema neste particular $\mathrm{e}$, assim, exigir atenção dos profissionais quanto à operacionalização das categorias stare decisis, analogia, distinção, superação, ratio decidendi e obter dicta. Por fim, quanto à metodologia empregada, destaca-se que na fase de investigação foi utilizado o método indutivo, na fase de tratamento de dados o cartesiano e o texto final foi composto na base lógica dedutiva. Nas diversas fases da pesquisa, foram acionadas as técnicas do referente, da categoria, do conceito operacional e da pesquisa bibliográfica.

PALAVRAS-CHAVE: Jurisprudência; Precedentes Jurisprudenciais; Normas Jurídicas; Decisão Judicial.

"Juiz de Direito; Doutor em Ciência Jurídica pela Universidade Vale do Itajaí (UNIVALI) Brasil com dupla titulação em Doutorado pela Università degli Studi di Perugia (UNIPG) Itália; Docente no Programa de Pós-graduação Stricto sensu em Ciência Jurídica da UNIVALI, da Escola da Magistratura de Santa Catarina (ESMESC), da Acadêmia Judicial (AJ), Brasil; E-mail: olzanon@yahoo.com.br

** Juiz de Direito; Doutorando em Direito pelo Programa de Pós-graduação em Direito (PPGD/UFSC) da Universidade Federal de Santa Catarina, Brasil; Membro do IBDP, Brasil. 


\title{
DISCUSSIONS ON THE POWER OF JURISPRUDENCE ON THE NEW CODE OF CIVIL LAW
}

\begin{abstract}
The gravitational force of preceding jurisprudential acts on determining factors in juridical decision-taking is analyzed. Criteria are also established with regard to its occurrence in Brazil especially in the wake of the new Code of Civil Law. The above is especially due to a great increase in the importance of decisions, particularly the higher courts, as persuasive arguments for the formation of juridical conviction. Jurisprudence is actually a hierarchical juridical source which is decisive within the Brazilian juridical scenario, ranking below Normative Texts and Juridical Principles. Their relevance does not lie with that which is judged but in the presentation of arguments for the solution of similar cases (structured basis) to improve the launching of juridical decisions. Increase the coherence of Juridical ordering and to preserve the institutional history of law. Further, the New Civil Code provided a different treatment to the gravitational force of Jurisprudence within the Brazilian conditions by changing the functioning of the system in this specific point and requires the attention of professionals with regard to the operationalization of the stare decisis categories, analogy, distinction, exceeding, ratio decidendi and obter dicta. At the end of the investigation, the inductive method was employed; the Cartesian method was employed for data treatment and the final text was composed within the deductive logical basis. Reference, category, operational concept and bibliographical research were employed during the different phases of the research.
\end{abstract}

KEY WORDS: Jurisprudence; Jurisprudential precedents; Juridical norms; Juridical decision.

\section{APUNTES INICIALES SOBRE LA FUERZA GRAVITACIONAL DE LA JURISPRIDENCIA EN EL NUEVO CÓDIGO DE PROCESO CIVIL}

RESUMEN: El objetivo (o referente) de este texto es tratar de la fuerza gravitacional de los precedentes jurisprudenciales como elementos de determinación de la toma de decisiones judiciales y, también, establecer algunos criterios cuanto a su incidencia en el contexto brasileño, mayormente considerando en Nuevo Código Civil (NCPC). La motivación para tratar de este tema sucede del notable aumento de la importancia de las decisiones de los tribunales, especialmente los superiores, como argumentos persuasivos para la formación de la convicción judicial en el escenario brasileño. Las conclusiones fueron en el sentido de que la Jurisprudencia es una Fuente Jurídica de jerarquía decisiva en el escenario jurídico brasileño, posicionada tras los Textos Normativos y los Principios Jurídicos, cuya relevancia 
reside no en el sentido del juzgado (dispositivo), pero sí en la presentación de los argumentos pertinentes para la resolución de casos semejantes (fundamentación estructurada), de modo a perfeccionar el lanzamiento de decisiones judiciales, aumentar la coherencia del ordenamiento Jurídico y preservar la historia institucional del Derecho. También se ha aclarado que el NCPC ha conferido un tratamiento especial a la fuerza gravitacional de la Jurisprudencia en el escenario brasileño, de modo a alternar el funcionamiento del sistema en este quesito particular y, así, exigir atención de los profesionales cuanto a la operación de las categorías stare decisis, analogía, distinción, superación, ratio decidendi y obter dicta. Por fin, cuanto a la metodología empleada, se destaca que en la fase de investigación fue utilizado el método inductivo, en la fase de tratamiento de datos el cartesiano y el texto final fue compuesto en la base lógica deductiva. En las diversas fases de la pesquisa, fueron accionadas las técnicas del referente, de la categoría, del concepto operacional y de la pesquisa bibliográfica.

PALABRAS-CLAVE: Jurisprudencia; Precedentes Jurisprudenciales; Normas Jurídicas; Decisión Judicial.

\section{INTRODUÇÃO}

O objetivo (ou referente) do presente texto é tratar da força gravitacional dos precedentes jurisprudenciais como elementos de determinação na tomada de decisões judiciais e, também, estabelecer alguns critérios quanto à sua incidência no contexto brasileiro, mormente considerando o Novo Código de Processo Civil (NCPC).

A motivação para tratar deste assunto decorre do notável aumento da importância das decisões dos tribunais, notadamente os superiores, como argumentos persuasivos para formação da convicção judicial no cenário brasileiro. Muito embora o sistema jurisdicional brasileiro esteja corretamente classificado entre os codificados (civil law ou code based legal system), o posicionamento das cortes tem adquirido eficácia cada vez mais decisiva no convencimento racional dos juízes e, em alguns casos, a própria legislação tem assegurado grau de potência mais elevado (até intransponível ou vinculante) para decisões proferidas em determinadas circunstâncias, cabendo mencionar os mecanismos processuais consistentes nas súmulas vinculantes, no procedimento para resolução de recursos repetitivos e no impedimento de admissão de certos recursos. Daí se pode extrair um 
intercruzamento com o padrão de construção jurisprudencial do direito (common law ou judge made law), em atenção à força gravitacional conferida às deliberações judiciais pretéritas na resolução dos casos posteriores. Outrossim, o tratamento de tal assunto adquire considerável importância, para compreensão de seus efeitos, positivos e/ou negativos, na consolidação de um sistema judicial mais sofisticado.

Com o objetivo de contribuir para essa discussão, o presente artigo está estruturado em dois subitens, iniciando pela apresentação dos conceitos operacionais relevantes para compreensão do assunto e, posteriormente, seguindo pela proposição de alguns critérios práticos acerca da atividade de deliberação judicial.

Iniciando o tratamento teórico em prol de tal desiderato, o primeiro item de texto apresentará o conceito operacional de Jurisprudência e suas peculiaridades. Ademais, será tratado sobre a eficácia dos Precedentes Jurisprudenciais como parâmetros de julgamento. Aqui, as hipóteses a serem investigadas dizem respeito, primeiro, à legitimidade (ou não) da atuação jurisdicional na criação de padrões de julgamento; e, segundo, acaso respondido positivamente ao ponto antecedente, perquirir qual a posição que a Jurisprudência assume entre as demais Fontes Jurídicas.

Em um segundo momento, serão propostos alguns critérios no tocante ao emprego da Jurisprudência na tomada de decisão, de acordo com os mecanismos processuais do cenário brasileiro, sobretudo pelas novas disposições introduzidas pelo NCPC.

Fixado o referente e estabelecidas as hipóteses a serem discutidas, cabe fazer alguns registros quanto à metodologia empregada, no sentido de que na fase de investigação foi utilizado o método indutivo, na fase de tratamento de dados o cartesiano e o texto final foi composto na base lógica dedutiva. Nas diversas fases da pesquisa, foram acionadas as técnicas do referente, da categoria, do conceito operacional e da pesquisa bibliográfica, recomendadas por César Pasold ${ }^{03}$.

\section{CONCEITO OPERACIONAL DE JURISPRUDÊNCIA}

Esta primeira seção é voltada à apresentação do conceito operacional de

\footnotetext{
${ }^{03}$ PASOLD, César. Metodologia da pesquisa jurídica: Teoria e prática. 12 ed. São Paulo: Conceito, 2011.
} 
Jurisprudência e de suas peculiaridades (item 2.1). Feito isto, serão investigadas as hipóteses referentes, primeiro, à legitimidade (ou não) da atuação jurisdicional na criação de parâmetros de julgamento (item 2.2); e, segundo, acaso respondido positivamente ao ponto antecedente, perquirir qual a posição que a Jurisprudência assume entre as demais Fontes Jurídicas (item 2.3).

\subsection{CONCEITO OPERACIONAL DE JURISPRUDÊNCIA}

Inaugurando o assunto, cabe assinalar que um precedente, em sentido amplo (latu sensu), é uma decisão sobre um determinado tema específico e que, por estar registrada em um repositório reconhecido, pode ser consultada como orientação para futuras análises de casos similares.

A sua importância na formação da convicção do órgão decisor não reside apenas em informar qual o comando pretérito adotado (dispositivo), mas sim, principalmente, em fornecer os argumentos que foram suscitados e empregados para ensejar tal deliberação (fundamentação ou motivação), pois ali residem elementos relevantes para conformação de novas decisões em circunstâncias similares.

Outrossim, é a exposição articulada e justificada das premissas de julgamento, não o resultado do julgamento isoladamente considerado, que confere importância (e utilidade) ao precedente, seja ele tomado na esfera privada ou pública.

A expressão Precedente Jurisprudencial, por sua vez, merece ser reservada especificamente para a decisão pretérita tomada pelo Poder Judiciário, que representa o âmbito estatal específico para tomada institucionalizada de decisões jurídicas. Outrossim, diferencia-se dos precedentes em geral especificamente em razão da autoridade da qual emana, que é qualificada constitucionalmente para tal atividade.

A categoria Jurisprudência, de outro lado, significa o conjunto de deliberações pretéritas de algum dos órgãos do Poder Judiciário, como lembra Dimitri Dimoulis ${ }^{04}$.

Feitas estas considerações preliminares, cabe justificar que a Jurisprudência (conjunto dos Precedentes Jurisprudenciais) é considerada uma das Fontes Jurídicas que informam a tomada de decisões jurídicas, com considerável eficácia, consoante a proposição pós-positivista da Teoria Complexa do Direito, construída em texto anterior por um dos coautores deste texto, visando superar o Positivismo

\footnotetext{
${ }^{04}$ DIMOULIS, Dimitri. Manual de Introdução ao estudo do direito. 4 ed. São Paulo: RT, 2011. p. 178.
} 
Jurídico e as chamadas correntes Neoconstitucionalistas, sem implicar concessões ao superado modelo do Jusnaturalismo ${ }^{05}$. No ponto, cabe destacar que a adoção deste marco teórico específico visa justamente evitar a necessidade de rediscussão de suas premissas bases (notadamente, dos conceitos operacionais de Fontes, Normas, Ordenamento e Decisão) e, assim, permitir sua apresentação direta para viabilizar a discussão ora proposta, razão pela qual se remete a discussão crítica de tais pressupostos para texto anterior específico sobre o tema ${ }^{06}$.

Outrossim, cabe aqui, antes de prosseguir, apresentar uma brevíssima síntese das categorias Norma, Fontes e Ordenamento, de acordo com a teoria antes mencionada, de modo a permitir o tratamento das hipóteses objeto do presente estudo.

Com este desiderato, importa assinalar que a referida proposição teórica estabelece que não existe Norma Jurídica em abstrato, sob a forma estrutural de Regra ou Princípio de um determinado Ordenamento, antes do advento do caso concreto a ser resolvido. Sem embargo, ela precisa ser construída pelo órgão julgador para servir de resposta resolutiva, em cada situação específica, mediante uma complexa atividade intelectual pautada nas provas de fatos (elementos de aproximação com a realidade) e nas Fontes Jurídicas legítimas (elementos de determinação). Ora, justamente porque não existem respostas prévias (normatividade) para perguntas que ainda não foram feitas (casos concretos), a Norma Jurídica consubstancia uma inédita solução concebida pelo decisor em toda nova hipótese de julgamento, ainda que vise imitar fielmente as deliberações já tomadas anteriormente para situações similares, consoante lembra Lenio Luiz Streck ${ }^{07}$.

\footnotetext{
${ }^{05}$ A Teoria Complexa do Direito é uma proposição de avanço teórico para a Teoria Jurídica (ou, acaso se preferir, para a Ciência Jurídica), caracterizada por assimilar os ganhos do modelo do Positivismo Jurídico e propor modificações que visam, de um lado, aumentar sua fidelidade na descrição da realidade (âmbito descritivo) e, de outro, aprimorar sua resolubilidade prática (aspecto prescritivo). Não é ocioso destacar que se trata de uma proposta diferente das correntes neopositivista (Ferrajoli), substancialista (Dworkin), procedimentalista (Alexy) e pragmática (Posner), mormente porque voltada a um paradigma mais do que juspositivista, sem retrocessos ao superado padrão jusnaturalista. Maiores detalhes constam do seguinte texto: ZANON JUNIOR, Orlando Luiz. Teoria complexa do direito. 2 ed. Curitiba: Prismas, 2015.

${ }^{06}$ A referida discussão sobre a modificação dos conceitos operacionais de Normas, Fontes, Ordenamento e Decisão, em detrimento do modelo juspositivista clássico, está longamente desenvolvida em: ZANON JUNIOR, Orlando Luiz. Teoria complexa do direito. 2 ed. Curitiba: Prismas, 2015. p. 71-123 e 157-225.

${ }^{07}$ STRECK, Lenio Luiz. Verdade e consenso: constituição, hermenêutica e teorias discursivas. 4 ed. São Paulo: Saraiva, 2011. p. 549-550: "Desde já - embora essa discussão já esteja esclarecida no decorrer da obra -, é necessário (re)lembrar que, para os efeitos aqui pretendidos, a palavra 'norma' representa o produto da interpretação de um texto, isto é, o produto da interpretação da regra jurídica realizada a partir da materialidade principiológica. Se sempre há um princípio atrás de uma regra, a norma será o produto dessa interpretação, que se dá na applicatio. [ ] Desse modo, não pode haver um conceito de norma que seja prévio e anterior ao caso a ser decidido. Portanto, a norma e, máxime, a normatividade do direito emerge da conflituosidade própria do caso".
} 
Nessa linha de raciocínio, o intérprete e aplicador (a exemplo do juiz) não dispõe de uma Norma Jurídica para resolver o caso concreto, consoante a ilusão de parcela das correntes juspositivistas, no sentido de que existiriam Normas Jurídicas em abstrato, formando um Ordenamento Jurídico, para solucionar (quase) todos os futuros casos que possam surgir. Isto significaria incorrer na chamada Falácia da Resposta Perdida (Lost Answer Fallacy), conceituada como a ficção metafísica de que as Normas Jurídicas existem em abstrato, sob a forma de pré-respostas perdidas em um sistema jurídico (floating out there), aguardando a ocorrência posterior de casos concretos que visam resolver, mediante silogismo lógico dedutivo (subsunção $)^{08}$.

Ao invés disto, é preciso adotar uma postura científica mais realista (ou seja, mais fielmente descritiva da realidade), no sentido de que o intérprete e aplicador não tem ao seu dispor uma Norma Jurídica, mas sim precisará construí-la em cada nova decisão (julgamento), dispondo apenas de determinadas Fontes Jurídicas, construídas artificialmente, que servem como guia de orientação na sua atividade jurígena.

Outrossim, Norma Jurídica pode ser entendida como o resultado da produção normativa na modalidade aplicação, com pretensão de correção, consistente na articulação das Fontes Jurídicas para formulação de um direcionamento de conduta diante de determinados fatos pretéritos aferidos por aproximação, sem olvidar de eventuais influxos de outras áreas do conhecimento, a serem admitidos a depender da argumentação quanto à sua relevância na espécie ${ }^{09}$.

No ponto, cabe asseverar que, num modelo de Estado de Direito, o órgão julgador não pode tomar qualquer decisão que lhe aprouver, de acordo com seu entendimento subjetivo sobre as melhores alternativas, sob pena de incorrer em arbitrariedade, cabendo-lhe respeitar as limitações previamente estabelecidas no cenário democrático, as quais são justamente as Fontes Jurídicas. Nesta ótica, elas configuram os elementos que determinam a atividade deliberativa, impondo limitações ao intérprete e aplicador.

Ademais, nem todo argumento pode ser legitimamente empregado como critério de julgamento, mas tão somente aqueles que foram devidamente

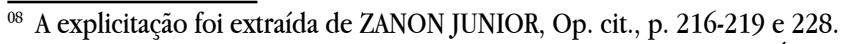

${ }^{09}$ Ibid., p. 197-215 e, especificamente na p. 229: "Norma jurídica: É o resultado da produção normativa na modalidade aplicação, com pretensão de correção, consistente na articulação das Fontes Jurídicas para formulação de um direcionamento de conduta diante de determinados fatos aferidos por aproximação, a sem olvidar de eventuais influxos de outras áreas do conhecimento, a serem admitidos a depender da argumentação quanto à sua relevância na espécie".
} 
incorporados na tradição jurídica de cada comunidade, para fins de surtir efeitos institucionais.

Daí que se pode conceituar Fontes Jurídicas como os argumentos teóricos (elementos de determinação) admitidos pelo Direito como legítimos limitadores para tomada de decisões em uma Sociedade específica. E, dentre elas, cabe mencionar os Textos Normativos, os documentos depositados num banco de Jurisprudência, os estudos de Doutrina publicados e os Princípios extraíveis de tal acervo, bem como os Costumes e os parâmetros da Ética aferidos sociologicamente, sem olvidar de incursões em tema interdisciplinares ${ }^{10}$.

E o conjunto de tais parâmetros decisórios (e não de Normas) é que forma o Ordenamento Jurídico. Sem embargo, é tal material concretamente existente que o órgão decisor tem a sua disposição para consultar e, com base nele, propor uma resposta para o problema emergente no tecido social, estruturada sob a forma de Norma Jurídica ${ }^{11}$.

Daí que a Jurisprudência, neste contexto, representa uma das Fontes Jurídicas legítimas para sustentar a tomada de decisões jurídicas. Sem embargo, é inegável a sua importância como critério decisório, porquanto se trata de argumento decisivo para construção da Norma Jurídica resolutória de cada caso concreto. Tratase de substrato relevante não só para anular determinadas posições jurídicas, que contrariam o posicionamento historicamente adotado pelos tribunais, mas também como parâmetro decisivo para fixar os precisos contornos de uma decisão jurídica. Mais do que isto, trata-se de critério de grande relevância para fins de fixação da coerência institucional histórica, no sentido de permitir o acompanhamento da evolução dos entendimentos dentro de um determinado sistema e, assim, evitar eventuais arbitrariedades.

Fixada a abrangência do conceito operacional de Jurisprudência, importa passar para as duas hipóteses objeto deste primeiro item do texto, referentes, primeiro, à legitimidade (ou não) da atuação jurisdicional na criação de parâmetros de julgamento (item 2.2); e, segundo, acaso respondido positivamente ao ponto antecedente, perquirir qual a posição que os Precedentes Jurisprudenciais assumem entre as demais Fontes Jurídicas (item 2.3).

\footnotetext{
${ }^{10}$ Ibid., p. 228: "Fontes Jurídicas: São os argumentos teóricos (elementos de determinação) admitidos pelo Direito como legítimos limitadores para tomada de decisões em uma Sociedade específica".

${ }^{11}$ Ibid., p. 228: "Ordenamento Jurídico: É o conjunto sistêmico de elementos de determinação adotados em determinada comunidade, sob a forma estrutural de uma órbita centralizada formal e materialmente pela Constituição".
} 


\subsection{CRIAÇÃO DE CRITÉRIOS DE JULGAMENTO PELO PODER JUDICIÁRIO}

Sobre o primeiro ponto, a discussão reside em torno da constatação real e concreta de que o Poder Judiciário é um órgão produtor de critérios de julgamento, ao lado do Legislativo e do Executivo, justamente porque os textos através dos quais expressa seus julgamentos passam a constituir uma Fonte Jurídica, ou seja, um critério determinante para deliberações posteriores.

Mais do que isto, a jurisdição pode inclusive exercer o controle de constitucionalidade sobre os textos legais estabelecidos pelos parlamentares, mediante uma inegável reavaliação política de sua adequação às diretrizes que irradiam do núcleo do sistema (a centralidade constitucional).

Diante de tal realidade incontestável, é evidente que a doutrina que atribui aos juízes a qualificação de servidores públicos em sentido estrito é insustentável, haja vista que são efetivamente agentes políticos integrantes de um dos poderes do Estado que, justamente no exercício desta função, têm a atribuição institucional de criar parâmetros de julgamento a serem considerados nas atividades de deliberação e, também, de fiscalizar a compatibilidade dos padrões legais fixados pelos demais poderes.

Porém, é muito importante salientar que os juízes são agentes políticos muito distintos dos congressistas e também dos membros da cúpula executiva, haja vista que os contornos das suas competências institucionais são traçados em torno de uma atividade precipuamente vinculada e limitada aos casos submetidos à arena processual, para fins de dirimir controvérsias sobre a ordem jurídica, evitando a sua inserção em debates externos à tal esfera.

Mais relevante ainda é reconhecer que a atuação política da jurisdição não pode apresentar cunho partidário, sob pena de flagrante vício institucional.

Corroborando o exposto, Dworkin afirma que "o Direito, assim concebido [como um conceito interpretativo], é profunda e inteiramente político", de modo que "juristas e juízes não podem evitar a política no sentido amplo da teoria política", entretanto, "o Direito não é uma questão de política pessoal ou partidária, e uma crítica do Direito que não compreenda essa diferença fornecerá uma compreensão pobre e uma orientação mais pobre ainda"12.

Seguindo esta trilha lógica, a produção de critérios de julgamento pode

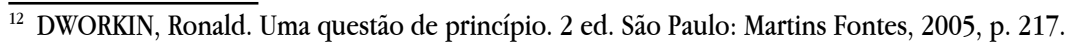


se dar em duas atividades distintas e complementares, sendo a primeira por positivação, quando os legisladores promover o processo legiferante para, após discussões partidárias, estabelecer comandos impessoais escritos; e, a segunda por aplicação, quando os juízes resolvem as questões inseridas em processos judiciais para, depois de embates técnicos desenvolvidos consoante as regras do discurso, construir os fundamentos que visam resolver a uma causa específica e, assim, servem de orientação para casos similares futuros ${ }^{13}$.

Portanto, encerrando esta primeira hipótese, é possível confirmar a legitimidade da jurisdição para construção da Fonte Jurídica na modalidade específica de Jurisprudência, no exercício da atividade política que lhe é especificamente reservada pela Constituição da República.

\subsection{JURISPRUDÊNCIA COMO FONTE JURÍDICA}

E, quanto à segunda e última hipótese de discussão deste primeiro item de texto, cabe referir que a Jurisprudência merece ser qualificada como uma Fonte Jurídica de notável força no conjunto dos elementos de determinação considerados como válidos e pertinentes no Ordenamento Jurídico brasileiro.

Nesse particular, a Teoria Complexa do Direito propõe uma hierarquização das Fontes Jurídicas em quatro graus de intensidade distintos, de acordo com a tradição institucional brasileira. Evidentemente que tal classificação das forças limitativas dos diversos padrões de julgamento não é uma imposição legal expressa, mas sim, uma construção teórica decorrente da interpretação da nossa tradição jurídica, a qual é relevante para auxiliar na argumentação jurisdicional, de modo a otimizar a operação interpretativa e aplicativa.

De acordo com ela, pode-se mencionar que as Fontes Jurídicas têm: a) eficácia intransponível, quando não podem ser contrariadas pelo intérprete e aplicador na sua atividade deliberativa, sob pena de sua conclusão ser considerada equivocada, de acordo com os parâmetros vigentes perante determinada Sociedade (exemplo: Textos Normativos); b) força vinculante, na hipótese de que uma determinada modalidade de Fonte Jurídica não pode ser simplesmente desconsiderada pelo intérprete, estando ele vinculado à menção de tal padrão de julgamento, muito embora, eventualmente a operação deliberativa possa implicar

13 ZANON JUNIOR, Orlando Luiz. Produção jurídica: positivação e aplicação. Âmbito Jurídico, n. 112, Rio Grande, Disponível em <www.ambito-juridico.com.br > . Acesso em 21.09.2015. 
a prevalência de outro critério decisório diverso, desde que mais forte ou de igual eficácia (exemplo: Jurisprudência, em certos casos); c) influência decisiva, no sentido de que o padrão de julgamento é transponível e não vincula o intérprete, mas se trata de um argumento relevante para deliberação, cuja desconsideração merece uma justificativa plausível, no curso do discurso jurígeno, sob pena de crítica (exemplo: Jurisprudência, em casos genéricos, e Políticas Executivas); e, d) força limitada, que é atribuída aos padrões de julgamento que podem ser importantes para decisão, porém sua observância não é necessariamente obrigatória e, ademais, não podem contrariar os elementos decisórios mais fortes, antes mencionados (exemplo: Costumes) $)^{14}$.

De acordo com tal proposta teórica, verifica-se que a Jurisprudência pode ser, grosso modo, situada logo abaixo dos Textos Normativos e dos Princípios Jurídicos quanto ao seu grau de eficácia, ostentando influência decisiva. Porém, não se desconhece que a própria Constituição da República pode estabelecer grau de potência mais intenso, atribuindo-lhe caráter intransponível ou vinculante, de acordo com a forma processual e o grau de hierarquia em que é produzido o texto jurisprudencial.

Aqui cabe fazer um esclarecimento, para reiterar que o grau de força da Jurisprudência como Fonte Jurídica não dimana simplesmente do seu dispositivo isoladamente considerado, mas sim da fundamentação empregada para justificar tal deliberação.

Ou seja, o quê confere eficácia aos precedentes como padrões de julgamento a serem respeitados é, precisamente, a motivação exposta pelo órgão jurígeno. Em outros termos, a força gravitacional da Jurisprudência reside nos fundamentos declarados nos textos das sentenças e dos acórdãos, que representam a construção jurídica individual resolutória do respectivo caso.

Isto porque, muito embora cada Norma Jurídica seja resultado de uma nova e única construção (pois não existe reload de espaço e tempo), mesmo assim ela pode servir de orientação a ser imitada para solução de novas controvérsias, inclusive com o objetivo de manter a coerência institucional.

E isto implica duas modestas recomendações práticas, uma para atividade judicante e outra para postulatória.

Quanto à jurisdição, é salutar que os órgãos julgadores colegiados

\footnotetext{
$\overline{14}$ ZANON JUNIOR, Orlando Luiz. Teoria complexa do direito. 2 ed. Curitiba: Prismas, 2015. p. 172-176 e 183.
} 
apresentem uma organização estruturada dos argumentos que serão objeto de julgamento, para o fim de que a votação expresse exatamente quais foram acolhidos ou rejeitados no resultado final.

Ora, é problemática a conduta de membros de colegiados que apresentam fundamentação sem sopesar os argumentos expostos pelos demais integrantes do órgão de deliberação, precisamente porque impede a dialética que é o motivo da adoção da modalidade coletiva de julgamento. Como resultado de tal postura profissional, a decisão conjunta pode até ter um dispositivo único, porém sua função precípua de orientação de casos futuros, para fins de afastamento de incertezas sobre os limites da interpretação, resta severamente prejudicada.

Como bem alerta Marcelo Neves, trata-se de um defeito organizacional presente inclusive no Supremo Tribunal Federal, em que "cada Ministro apresenta votos (geralmente longuíssimos) em separado, aduzindo argumentos e razões os mais diversos", de modo que "não é comum que cheguem aos mesmos resultados com os argumentos os mais diferentes", resultando em um acórdão inconsistente, pois "cada um aduz argumentos que, em alguns casos, são incompatíveis"15.

Notadamente, o mais adequado é seguir uma discussão ordenada, através do elenco dos pedidos a serem discutidos e de todos os argumentos favoráveis e contrários, com o objetivo de, ao final, produzir um acórdão fundamentando com bases nas teses prevalecentes (e indicando claramente as rejeitadas), de modo que tenha a capacidade de orientar as futuras tomadas de decisões em Sociedade.

E, no tocante à postulatória, cabe assinalar que não basta o advogado simplesmente elencar uma série de ementas de julgados proferidos por tribunais distintos para o fim de reforçar uma posição supostamente mais favorável à pretensão deduzida na petição, cabendo-lhe, isto sim, trabalhar especificamente com a semelhança fática entre o fato analisado no julgado e aquele em discussão no processo e, mais do que isto, levantar os fundamentos expostos no acórdão para construir a pretensão (to make a case). Somente então é que o órgão julgador realmente estará compelido a responder a tese proposta, para refutá-la ou acolhê-la, ainda que de forma sucinta. E, justamente por isto, é que a redação do art. $489, \S$ $1^{\circ}$, incisos I a VI, do NCPC implica um esforço argumentativo não só ao juiz, mas também e principalmente ao advogado, a quem cabe construir a tese para o fim de

\footnotetext{
${ }_{15}$ NEVES, Marcelo. Entre Hidra e Hércules: princípios e regras constitucionais como diferença paradoxal do sistema jurídico. 2 ed. São Paulo: Martins Fontes, 2014, p. 199. Na sequência, expõe diversas falhas oriundas do problema em tela.
} 
que seja levada em consideração.

\section{CRITÉRIOS DE APLICAÇÃO NO CENÁRIO BRASILEIRO}

Balizadas as premissas teóricas do presente estudo, cumpre analisar a forma de aplicação dos precedentes jurisprudenciais na ordem jurídica nacional. Para tanto, a par de se aproveitar as valiosas lições do direito alienígena, o ponto de partida será a análise do NCPC, que inova no ordenamento jurídico, ampliando largamente a utilização do precedente como elemento de determinação para a tomada da decisão judicial. Neste ponto, a novel legislação processual civil forma um sistema de precedentes próprio que, apesar de não se identificar com um sistema de common law, utiliza algumas de suas ferramentas para a formulação de critérios de utilização das decisões pretéritas como argumentos juridicamente válidos.

\subsection{A IDEIA DE STARE DECISIS NO DIREITO BRASILEIRO}

Poder-se-ia falar que o NCPC está, de forma peculiar, trazendo a noção de stare decisis ao direito pátrio. A stare decisis é a doutrina criada para dar força vinculativa ao precedente (binding precedent) para casos futuros. "Deixe ficar o que já foi decidido" é seu princípio básico, ou seja, frente a um precedente aplicável à espécie, o juiz deve segui-lo, pois ele não representa somente uma evidencia do que seria o direito apropriado, mas é o direito em si (law itself).

O stare decisis, contudo, não pode ser confundido com o common law. Vale lembrar que o common law prescinde - e efetivamente prescindiu - de uma teoria do precedente representada pela stare decisis. Somente no século XVIII, portanto algo relativamente recente no contexto histórico, a doutrina do precedente surgiu e se desenvolveu nos países de common law. Assevera Marinoni que "o stare decisis constitui apenas um elemento do moderno common law, que também não se confunde com o common law de tempo imemoriais ou com os costumes gerais, de natureza secular, que dirigiam o comportamento dos Englishmen" Adiante, avança o autor, afirmando que a ideia de stare decisis é imprescindível mesmo ao direito brasileiro, citando exemplos do STF, sobretudo na evolução dos efeitos vinculantes dos motivos determinantes da decisão em sede de recurso

\footnotetext{
${ }^{16}$ MARINONI, Luiz Guilherme. Precedentes obrigatórios. 3 ed. São Paulo: RT, 2013, p. 32.
} 
extraordinário. ${ }^{17}$ Indiscutivelmente, é crescente a ideia do uso dos precedentes como fonte de direito, como salienta Streck. ${ }^{18}$

Em que pese ser cotada como fonte do direito, a dogmática tradicional (positivista) ainda não encontrou lugar próprio à jurisprudência na hierarquia das fontes, mas, ainda assim, é crescente o seu valor para o julgamento de causas futuras. Vários são os exemplos da influência da ideia de stare decisis no direito brasileiro - ainda que com ela não se confunda, devendo ser lembrada a súmula vinculante (art. 103-A da Constituição Federal), o valor que a legislação processual civil já dá a jurisprudência dominante ou súmula dos tribunais (art. $475, \S 3^{\circ}$; art. 518, $\S 1^{\mathrm{o}}$; art. $544, \S 3^{\circ}$; e, art. 557, todos do CPC), o julgamento diferenciado de causas repetitivas (art. 285-A, do CPC), além da repercussão geral (art. 543-B do CPC).

Para a aplicação do stare decisis, ou de qualquer instrumento assemelhado, há a necessidade de grande consistência na jurisprudência, ou seja, que ela se mantenha minimamente estável, sem quebras a cada novo caso. Se a cada nova lide o órgão julgador expor uma tese diferente da utilizada em situação similar anterior, sem ao menos considerá-la, estará fadado qualquer esforço para a criação de um sistema de precedentes. Por isso a preocupação do NCPC em manter a jurisprudência dos tribunais uniformizada, de forma estável, íntegra e coerente (art. 926, caput, do NCPC), inclusive possibilitando a modulação de efeitos, em tribunais superiores, da decisão que apresentar uma quebra com a jurisprudência dominante anterior (art. 926, $\S 3^{\circ}$, do NCPC) e exigindo uma carga argumentativa maior para qualquer alteração jurisprudencial (art. 926, $\S 4^{\circ}$, do NCPC).

Obviamente, há uma convergência dos supracitados dispositivos com a teoria de Dworkin do "direito como integridade" (law as integrity). Não sendo o ponto central do presente estudo, basta sintetizar que, em Dworkin, a decisão judicial deve ser vista como um romance escrito a várias mãos, no qual cada julgador representa um romancista na corrente (chain novel). Logo, o juiz deve ler tudo o que foi julgado até então, para entender a história institucional do Direito, ou seja, o que seus antecessores construíram coletivamente, levando adiante esta empresa, obtendo, ao final, um todo harmônico, como se fosse obra de um único autor,

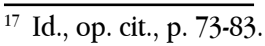

${ }^{18}$ STRECK, Lenio Luiz. Súmulas no direito brasileiro: eficácia, poder e função. Porto Alegre: Livraria do Advogado, 1998, p. 86. 
destaca Dworkin. ${ }^{19}$

Agasalhando esta noção de influência decisiva da jurisprudência no processo de tomada de decisão, outra preocupação do NCPC é que não ocorra o que Maurice Adams chama de uso oportunista do precedente, ou seja, que na construção do argumento jurídico não sejam utilizados apenas decisões pretéritas que confirmam a posição tomada pelo intérprete. ${ }^{20}$ Esta prática é comum no cenário brasileiro, em que há a multiplicação de ementas em peças processuais, sempre confirmando e legitimando a tese jurídica defendida, sem maiores preocupações com posicionamentos divergentes. A visão alternativa é simplesmente ignorada como se inexistente fosse. Em outras palavras, o precedente é utilizado como reforço da posição tomada, citando-se somente a mesma linha de pensamento, mas não enfrentando correntes jurisprudenciais concorrentes.

\subsection{ANALOGIA, DISTINÇÃO E SUPERAÇÃO DA JURISPRUDÊNCIA E DO PRECEDENTE}

Para combater este estado de coisas, o NCPC exige dos juristas a demonstração de distinções ou superações de jurisprudência ou precedentes levantados por qualquer um dos atores processuais (art. 489, $\S 1^{\circ}$, VI, do NCPC) e, de forma genérica, o dever de se analisar qualquer argumento que, em tese, possa infirmar a decisão tomada (art. 489, $\S 1^{\circ}$, IV, do NCPC).

Neste passo, um sistema de precedentes não engessa o sistema jurídico. Há, como afirmam Streck e Abboud, uma flexível vinculação, decorrente da necessidade do juiz que resolva um novo caso de "submeter os precedentes a teste de fundamentação racionao - vale dizer, o juiz não deve aceitar cegamente o precedente." ${ }^{21}$ Para o cumprimento de tais exigências, mecanismos como a analogia, distinção e superação (overruling), de uso pouco ordinário na prática jurídica - e,

\footnotetext{
${ }^{19}$ DWORKIN, Ronald. O império do direito. 2 ed. Tradução: Jefferson Luiz Camargo. São Paulo: Martins Fontes, 2007, p. 276. Para maior desenvolvimento do assunto, ver: LUIZ, Fernando Vieira. Teoria da decisão judicial: dos paradígmas de Ricardo Lorenzetti à resposta adequada à Constituição de Lenio Streck. Porto Alegre: Livraria do Advogado, 2013, p. 173-177.

${ }^{20}$ ADAMS, Maurice. The rhetoric of precedent and comparative legal research. Modern Law Review, n. 62, v. 3, 1999, p. 465-466: "I have endeavoured to demonstrate elsewhere that, despite academic arguments to the contrary, Belgian courts mostly cite precedents or case-law, if at all, in an opportunistic manner - ie, when they confirm the position taken by a court. Precedents are thus mainly used as a device to legitimate a judgment post factum."

${ }^{21}$ STRECK, Lenio Luiz; ABBOUD, Georges. O que é isto - o precedente judicial e as súmulas vinculantes? 3 ed. Porto Alegre: Livraria do Advogado, 2015, p. 51.
} 
em especial, judiciária - passam a deter uma grande relevância na construção dos argumentos jurídicos a partir da vigência do NCPC.

A analogia, destaca Neumann Jr., consiste na demonstração de que duas situações são tão similares que a argumentação que justifica a decisão em um caso deve ser adotada na seguinte. ${ }^{22}$ A distinção é o processo contrário, ou seja, observam-se tantas diferenças fundamentais entre os casos, que faz ceder qualquer justificativa na aplicação do caso anterior ao novo conflito. Por seu turno a superação (overruling) ocorre quando o tribunal verifica que o precedente estabelecido, a par de apresentar a similitude necessária, não deve ser mais aplicado. Isso ocorre, como destaca Marinoni, nos casos em que o precedente "deixa de corresponder aos padrões de congruência social e consistência sistêmica e, ao mesmo tempo, os valores que justificam a estabilidade mais fundamentam a sua revogação do que a sua preservação." ${ }^{3}$

No overruling, o precedente perde sua força e autoridade, tal qual uma lei expressamente revogada e um novo princípio jurídico é substitui antigo. As hipóteses de cabimento, segundo Tucci, ocorrem no caso do precedente "ser considerado ultrapassado ou, ainda, equivocado (per incuriam ou per ignorantia legis)" ${ }^{24}$. É bem verdade que nas cortes americanas, sustenta Nelson, há uma presunção contra a reversão de seus próprios precedentes. ${ }^{25}$ Em outras palavras, favorece-se a aplicação da stare decisis à prática do overruling. Como afirma Gerhardt, a rejeição de uma linha de precedentes pode enfraquecer e causar estragos ao próprio sistema jurídico. $^{26}$

Essa visão é compartilhada no comportamento dos tribunais que buscam justificativas especiais, e não a mera discordância de seus membros, para reverter uma decisão anterior. Por exemplo, em Patterson v. McLean Credit Union, a decisão da Suprema Corte Americana anotou que embora alguns de seus membros acreditassem que o precedente que regia o caso (Runyon v. McCrary) tivera sido decidido de forma equivocada, os juízes se mantiveram fiel ao julgamento anterior, uma vez que sua rejeição necessitaria de justificativas especiais, acima e além da

\footnotetext{
${ }^{22}$ NEUMANN JR., Richard K. Legal reasoning and legal writing: structure, strategy, and style. 5 ed. Aspen: Nova Iorque, 2005, p. 165: "An analogy is a demonstration that two situations are so parallel that the reasoning that justified the decision in one should do the same in the other."

${ }^{23}$ MARINONI, op. cit., p. 389.

${ }^{24}$ TUCCI, José Rogério Cruz e. Precedente judicial como fonte do direito. São Paulo: RT, 2004, p. 179.

${ }^{25}$ NELSON, Caleb. Stare decisis and demonstrably erroneous precedents. Virginia Law Review, v. 87, n. 1, p. 2 , mar. 2002.

${ }^{26}$ GERHARDT, Michael J. The role of precedent in constitutional decision-making and theory. George Washington Law Review, v. 60. p. 112-113, 1991.
} 
mera demonstração de erro. ${ }^{27}$ Por isso, assevera Alexander que se a incorreção da decisão anterior fosse condição suficiente para a reversão, não haveria qualquer constrição no precedente. $^{28}$

Há, portanto, um peso muito forte em favor da manutenção do precedente e a mudança de posicionamento exige da corte uma carga argumentativa extremamente elevada. Assim, como elucidam Vojvodic, Machado e Cardoso, "inovar implicava justificar muito bem o que estava mudando e por quê. A ruptura com um precedente claro exige maior argumentação, obriga o Tribunal a dialogar com a sua história." ${ }^{29}$ Isso ocorreu, por exemplo, quando a Suprema Corte Americana decidiu Brown $v$ Board of Education ${ }^{30} \mathrm{e}$, para reconhecer a inconstitucionalidade da política "separate but equal", fez o overruling de Plessy v. Ferguson. ${ }^{31}$

Embora a analogia não seja um recurso exclusivo dos sistemas anglosaxônicos, sendo certo que, como defende Langenbucher, cada ordenamento jurídico utiliza-a a seu modo ${ }^{32}$, é importante voltar os olhos para os países de common law, verificando como ocorre a analogia entre casos. Levi caracteriza o argumento pela analogia como um processo em três passos. Primeiro, o juiz observa a similaridade entre os casos, tanto nas questões de fato, como de direito. Em segundo lugar, ele verifica a regra legal aplicável ao primeiro caso. Por fim, em terceiro, ele aplica a mesma regra ao caso atual. ${ }^{33}$

Sunstein aponta que a analogia é uma das formas pelas quais diferentes interpretes podem chegar a um acordo prático em questões de controvérsia moral, pois mesmo aqueles que discordam no nível teórico podem concordar com as possíveis analogias entre dois casos. ${ }^{34}$ Portanto, a analogia, na apreciação da similitude entre duas causas, não deve ser levada a cabo observando-se tão somente o resultado do caso anterior. Exige ela o conhecimento não só do direito acobertado pela decisão anterior, mas também o profundo levantamento de toda a matéria de fato ocorrida. Assim, os aspectos jurídicos semelhantes apenas serão relevantes

\footnotetext{
${ }^{27}$ ESTADOS UNIDOS DA AMÉRICA. Patterson v. McLean Credit Union. U.S. Report, v. 491, p. 173-174, 1989.

${ }^{28}$ ALEXANDER, Larry. Constrained by Precedent, South California Law Review, v. 63, p. 56, 1989.

${ }^{29}$ VOJVODIC, Adriana de Moraes; MACHADO, Ana Mara França; CARDOSO, Evorah Lusci Costa. Escrevendo um romance, primeiro capítulo: precedentes e processo decisório no STF. Revista Direito GV, v. 5, p. 36, jan.-jun. 2009.

${ }^{30}$ ESTADOS UNIDOS DA AMÉRICA. Brown v Board of Education. U.S. Report, v. 347, p. 483, 1954.

31 ESTADOS UNIDOS DA AMÉRICA. Plessy v. Ferguson. U.S. Report, v. 163, p. 537, 1896.

32 LANGENBUCHER, Katja. Argument by analogy in the european law. Cambridge Law Journal, v. 57, p. 481, 1998. No original: "Argument by analogy also forms an integral part of legal reasoning. Arguably, every legal tradition employs some version of it to justify judicial decisions".

33 LEVI, Edward H. An Introduction to Legal Reasoning. Chicago: The University of Chicago Press, 1970, p. 2.

34 SUNSTEIN, Cass. R. Legal Reasoning and Political Conflict. Nova Iorque: Oxford University Press, 1996, p. 62-65.
} 
se os fatos alegados pelas partes e reconhecidos pela decisão sejam igualmente condizentes um com os outros. Por isso, a ausência da similitude entre as questóes jurídicas e as questões de fato, que afastam a aplicação de um precedente pode ser levado a cabo pelo processo de distinção (distinguishing).

No distinguishing, o juiz afasta a aplicação de determinado precedente, verificando que as circunstâncias fáticas das duas demandas (precedente e atual) não se mostram assemelhadas. Seja pela peculiaridade de uma ou de outra, o afastamento desta semelhança factual impede que seja dado o mesmo regramento jurídico. De outro modo, ainda que se mostrem as situações análogas, o diferente regramento jurídico estabelecido pelo direito impede a aplicação da mesma regra para os fatos de um e do outro processo. Assim, no distinguishing não há a possibilidade de analogia nas questões de fato ou de direito. Em outras palavras, a técnica consiste, como expõe Lagenbucher, na prova argumentativa de que uma certa linha de precedentes não é relevante para o caso que se trata. ${ }^{35}$

Importante assinalar que a similitude ou sua ausência constitui uma análise complexa, que está sempre sujeita a disputa, pois não é resolvida por uma lógica pura, como explicam Fletcher e Sheppard. ${ }^{36}$ No contexto do common law, "achar a similaridade e a diferença é o passo chave no processo legal" ${ }^{\prime 7}$ e, por isso, o trabalho primordial do advogado que litiga (litigator) é demonstrar à Corte as possíveis analogias com os precedentes que apresenta e distinções daqueles citados pela parte adversa. Com a vigência do NCPC, isto será necessário, também, na prática jurídica nacional, uma vez que a existência de argumentos jurídicos válidos à tomada de decisão dependerá da demonstração argumentativa destas similitudes e diferenças entre os casos.

Para possibilitar o exercício da analogia e distinção, na edição de súmulas, há a obrigação dos Tribunais em se aterem as circunstâncias fáticas dos precedentes que motivaram sua criação (art. 926, § $2^{\circ}$, do NCPC). Esta é a dicção do art. 489, $\S 1^{\circ}$, V e VI, do NCPC, ao afirmar que não se considera fundamentada a decisão que "se limitar a invocar precedente ou enunciado de súmula, sem identificar seus fundamentos determinantes nem demonstrar que o caso sob julgamento se

35 LANGENBUCHER, op. cit., p. 491. No original: "Distinguishing consists in the argumentative proof that a certain line of precedents is not relevant to the case at hand".

${ }^{36}$ FLETCHER, George P.; SHEPPARD, Steve. American Law: in a global context. Oxford University Press: Nova Iorque, 2005, p. 79: "Relationships of "more like-ness" are not a matter of strict logic. Reasonable people might disagree whether an airplane is more like a bird than an automobile or vice versa, or whether abortion is more like infanticide than like birth control. Analogies are subject to dispute. They are the stuff of disagreement and dissenting opinions."

${ }^{37}$ LEVI, op. cit., p. 2. No original, "The finding of similarity and difference is the key step in the legal process". 
ajusta àqueles fundamentos" (inciso $\mathrm{V}$ ), bem como explicita que incorre na mesma ausência de fundamentação a decisão que "deixar de seguir enunciado de súmula, jurisprudência ou precedente invocado pela parte, sem demonstrar a existência de distinção no caso em julgamento ou a superação do entendimento" (inciso VI).

Ainda que o NCPC tenha voltado estas exigências ao magistrado (ou Tribunal), fazendo-o expressamente em relação às partes apenas no art. 1.042, § $1^{\mathrm{o}}, \mathrm{II},^{38}$ este exercício argumentativo é um imperativo, como já visto, não voltado tão somente ao juiz, no momento da decisão. É algo em comum aos juristas em geral. Portanto, o advogado, o defensor público, o promotor de justiça, enfim, todos aqueles que militam em um processo judicial deverão construir seus raciocínios, suas teses, com uma percuciente análise dos fatos que embasaram a decisão anterior e seus fundamentos jurídicos, quando estiverem fundamentando com base em precedentes. A partir daí, o jurista poderá formular seu argumento, realizando as analogias que entender pertinentes, buscando nos fatos do caso em mão o suporte básico para esta comparação com o antecedente.

Caso o jurista que litigue em juízo não siga esse exercício argumentativo, continuando a despejar em suas peças processuais ou sustentações várias citações a ementas de decisões anteriores sem maiores considerações, o juiz simplesmente poderá ignora-las, sem que incida na hipótese do art. 489, VI, do NCPC. Contudo, se as partes apresentam corretamente seus argumentos, estabelecendo analogias e distinções e o juiz, inadvertidamente, não faz o mesmo, desconsiderando os precedentes evocados, reconhecer-se-á a falta de fundamentação, determinandose a anulação da sentença, para que outra seja lançada em seu lugar. Lembre-se, ainda, que se o juiz resolver o litígio com base em regras ou princípios diversos dos levantados pelas partes, extraídos de precedentes não debatidos no processo, deve, de antemão, oportunizar que as partes se manifestem, evitando a surpresa, na forma do art. 10 do NCPC..$^{39}$

\subsection{RATIO DECIDENDI E OBTER DICTA}

\footnotetext{
${ }^{38}$ Art. 1.042. Cabe agravo contra decisão de presidente ou de vice-presidente do tribunal que: [...] $\S 1$ 1o Sob pena de não conhecimento do agravo, incumbirá ao agravante demonstrar, de forma expressa: [...] II a existência de distinção entre o caso em análise e o precedente invocado, quando a inadmissão do recurso: a) especial ou extraordinário fundar-se em entendimento firmado em julgamento de recurso repetitivo por tribunal superior; b) extraordinário fundar-se em decisão anterior do Supremo Tribunal Federal de inexistência de repercussão geral da questão constitucional discutida.

${ }^{39}$ Art. 10. O juiz não pode decidir, em grau algum de jurisdição, com base em fundamento a respeito do qual não se tenha dado às partes oportunidade de se manifestar, ainda que se trate de matéria sobre a qual deva decidir de ofício.
} 
A questão que se põe é como realizar esta tarefa argumentativa a contento. Qual o procedimento ou a metodologia que indica corretamente o caminho a seguir? A analogia e a distinção (distinguishing), como visto, são os principais processos para a definição da aplicação ou não de determinado precedente ao caso concreto. Contudo, nestes processos, Fletcher e Sheppard indicam que dois são os principais limites em relação à interpretação do precedente..$^{40} \mathrm{O}$ primeiro é o de que o intérprete não está obrigado a aplicar toda a linguagem do precedente, mas tão somente suas porções essenciais, que representa a questão jurídica mais estreita, a ratio decidendi. ${ }^{41}$ A segunda é que a diferenciação entre ratio e dicta é feita não pelo juiz que decide o caso, mas pelo futuro interprete, que determinará a extensão da decisão anterior que o vincula no novo julgamento. ${ }^{42}$

Apesar da polissemia do termo ratio decidendi, como mostrada por Streck e Abboud, ${ }^{43}$ o conceito operacional dado, para fins do presente estudo, é definila como aquele princípio deduzido no precedente que foi essencial à decisão do caso, constituindo sua fundamentação, enquanto o obter dictum, como analisa Re, "é apenas uma observação ou opinião e, como tal, goza tão somente de força persuasiva”“4 . A razão de decidir não é exposta em um enunciado claro, não se encontrando na própria fundamentação da decisão. Exige do intérprete uma análise da postura processual até então adotada (relatório), de todas as circunstâncias fáticas e teses jurídicas enfrentadas (fundamentação), como a decisão final da Corte explicitando o comando judicial e o remédio apropriado ao caso (dispositivo). Por exclusão, aquilo que não se encaixa com ratio, será dictum. Neste caso, a parte da decisão que não é essencial ao resultado expressado pelo Tribunal não vinculará os

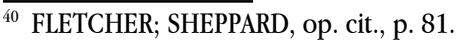

${ }^{41}$ Id., op. cit., loc. cit. No original: "The first is that a later court is bound to apply only the most essential portions of a precedent opinion, not all of the language in it". No mesmo sentido, expondo que é a ratio decidendi que terá força vinculativa, ver: SOUZA, Marcelo Alves Dias de. Do precedente judicial à súmula vinculante. Curitiba: Juruá, 2007, p. 125.

${ }^{42}$ Id., op. cit., p. 82. No original: "The delimitation of language in a precedential opinion into dicta and ratio is nearly always a matter for later judges and not for the judge who initially issued the precedent. It is excessively rare for a judge writing or speaking an opinion to identify the statements made as one or another, and in any event, such an identification would not be binding on a later judge".

${ }^{43}$ STRECK; ABBOUD. Op. cit., p. 47. “(...) é possível elencar sete conceitos cunhados pela tradição sobre ratio decidendi: 'é o critério decisional, ou seja, a regra que está subjacente à decisão; é o princípio de direito adotado para definir o conteúdo da demanda; é a premissa ou a passagem lógica que se revela necessária para se alcançar a decisão do caso; é a regra ou princípio que constitui a condição necessária ou suficiente; é o princípio de direito contido na decisão judicial e que é suficiente para decidir o caso concreto; é a argumentação explícita ou implícita necessária ou suficiente para definir o caso e, por último, é a relação entre resolução (motivada) do caso e o próprio caso, ou seja, o fato e as questões jurídicas inerentes'."

${ }^{44}$ RE, Edward D. Stare decisis. Revista de processo, v. 19, n. 73, São Paulo: RT, jan./mar., 1994, p. 2. 
futuros juízes, ainda que mantenham alguma autoridade persuasiva para questões similares.

Cumpre ressaltar que há quem defenda que a própria ementa de um determinado acórdão aponte, com clareza, a ratio do julgado. Em outras palavras, sintetiza de forma simples e acessível o que de principal foi decidido e, desta feita, expressa as razões de decidir do Tribunal. Ledo engano. Trabalhar com precedentes exige do intérprete a renúncia à mera busca e citação de ementas. Trata-se da alteração de um enraizado hábito cultural que se encontra, ainda, no senso comum teórico dos juristas, expressão cunhada por Warat. ${ }^{45}$

Como enfatizado, a recaracterização de uma decisão como precedente é tarefa do jurista que a utilizará no futuro e não do próprio Tribunal, no momento do julgamento da causa antecedente. Neste ponto, há profunda discordância em relação a qualquer efeito prospectivo (forward-looking aspect) do procedente, como já demonstrado por Lamy e Luiz. ${ }^{46}$ Isso porque, não pode haver respostas antes das perguntas, como adverte Streck, ${ }^{47}$ ou seja, o Tribunal que decide hoje um caso não consegue prever todas as hipóteses de aplicação do julgado como precedente no futuro. Isso dependerá da ocorrência de novos fatos, com peculiaridades irrepetíveis, imprevisíveis de antecipação pela Corte, que embasarão novas controvérsias.

As ementas, assim, são importantes no sentido de promover a catalogação dos casos julgados por determinado Tribunal, facilitando e racionalizando seu arquivamento para posterior uso. Na medida em que a profusão de julgados acarreta uma grande dificuldade em se organizar a informação que vai se acumulando, o uso de pequenos textos ou palavras-chaves auxiliam que um determinado acórdão de interesse seja recuperado e eventualmente valorado para sua aplicação futura. Sistemas de buscas, principalmente os eletrônicos, dependem de informações desta natureza. Neste passo, as ementas devem interessar a outras áreas de conhecimento, como a biblioteconomia, arquivologia e sistemas da informação. Contudo, na seara jurídica, não representam, por si só, as razões de decidir de determinado caso.

\footnotetext{
$\overline{45}$ WARAT, Luís Alberto. Mitos e teorias na interpretação da lei. Porto Alegre: Síntese, 1979, p. 19. "Chamar-se-á 'senso comum teórico' a essa montagem de noções - representações - imagens - saberes, presentes nas diversas práticas jurídicas, lembrando que tal conjunto funciona como um arsenal de ideologias práticas. Em outras palavras, essa montagem corresponde a norma que disciplinam ideologicamente o trabalho profissional dos juristas."

${ }^{46}$ LAMY, Eduardo de Avelar; LUIZ, Fernando Vieira. Contra o aspecto prospectivo do precedente: uma crítica hermenêutica a Frederick Schauer. Revista de Processo, v. 250, a. 40, p. 383-402. São Paulo: RT, dez. 2015.

${ }^{47}$ A expressão de que "não existem respostas antes das perguntas" é utilizada por Lenio Streck para defender que a norma (enquanto atribuição de sentido de um texto - e texto, aqui, é evento) só pode ser revelada frente ao caso a ser decidido, pois ocorre somente na applicatio, advinda da fusão de horizontes ocorrida no círculo hermenêutico. Sobre o assunto, ver: STRECK, Lenio Luiz. Verdade e consenso: constituição, hermenêutica e teorias discursivas. 4 ed. São Paulo: Saraiva, 2011, p. 461.
} 
Mesmo porque não há sequer o controle do órgão colegiado - que efetivamente julgou a causa - do conteúdo da ementa, que é tarefa exclusiva do relator.

Há um outro aspecto, em relação às ementas, já observado em estudo anterior. ${ }^{48}$ Trata-se da questão da ementa não corresponder efetivamente com o que foi decidido pelo Tribunal. Ainda que na seara criminal, um caso reflete bem esse problema, mesmo na Corte mais alta do país. Ressalta-se, de antemão, que o sistema de precedentes adotado pelo NCPC não se limita à jurisdição cível, abrangendo, de igual forma, a justiça criminal, mesmo não expressamente contida no art. 15 do $\mathrm{NCPC}^{49}$. Isso se dá pela autorização do art. $3^{\circ}$ do Código de Processo Penal (CPP) ${ }^{50}$ de suplementação por fontes auxiliares, ou algumas remissões diretas (e.g., art. 139, 362 e 790, todos do CPP). Não fosse tal fato, a aplicação subsidiária da legislação processual civil em processos criminais é amplamente aceita pela jurisprudência, sobretudo no STF, citando-se os casos de utilização em relação à perpetuação da competência (RHC n. 83181, RHC n. n. 83008 e HC n. 117871), ${ }^{51}$ substituição de testemunhas (AP n. 470 e ArAP n. 470), ${ }^{52}$ da necessidade de repercussão geral nos recursos extraordinários criminais (QO no AI n. 664567) $)^{53}$ e mesmo em relação a nulidades (HC n. 98664). ${ }^{54}$ Mesmo que se discorde da tese aqui defendida, o exemplo continua válido em relação à disfunção entre voto e ementa.

Passando-se ao caso, trata-se do Habeas Corpus (HC) n. 103.581, tendo como relator o Min. Luiz Fux. ${ }^{55}$ No julgamento, o relator apresentou seu voto, explorando todas as questões de fato e jurídicas, salientando, como tema central a inexistência de nulidade pelo fato dos então réus terem sido ouvidos como testemunhas durante

\footnotetext{
48 LUIZ, op. cit.

49 Art. 15. Na ausência de normas que regulem processos eleitorais, trabalhistas ou administrativos, as disposições deste Código lhes serão aplicadas supletiva e subsidiariamente.

${ }^{50}$ Art. $3^{\circ}$ A lei processual penal admitirá interpretação extensiva e aplicação analógica, bem como o suplemento dos princípios gerais de direito.

51 BRASIL. Supremo Tribunal Federal. Tribunal Pleno. Recurso em Habeas Corpus, n. 83181. Relator para o acórdão: Ministro Joaquim Barbosa. DJ 22.10.2004, p. 5. Disponível em: <www.stf.jus.br > . Acessado em: 10.02.2015. BRASIL. Supremo Tribunal Federal. Segunda Turma. Recurso em Habeas Corpus, n. 83008. Relator: Ministro Maurício Corrêa. DJ 27.06.2006, p. 5. Disponível em: <www.stf.jus.br>. Acessado em: 10.02.2015. BRASIL. Supremo Tribunal Federal. Primeira Turma. Habeas Corpus, n. 117871. Relatora: Ministra Rosa Weber. DJe 01.07.2015, p. 128. Disponível em: <www.stf.jus.br > . Acessado em: 10.02.2015.

52 BRASIL. Supremo Tribunal Federal. Tribunal Pleno. Ação Penal, n. 470. Relator: Ministro Joaquim Barbosa. DJe 08.10.2010, p. 190. Disponível em: <www.stf.jus.br > . Acessado em: 10.02.2015. BRASIL. Supremo Tribunal Federal. Tribunal Pleno. Agravo Regimental (segundo) em Ação Penal, n. 470. Relator: Ministro Joaquim Barbosa. DJe 03.03.2009, p. 79. Disponível em: <www.stf.jus.br >. Acessado em: 10.02.2015.

53 BRASIL. Supremo Tribunal Federal. Tribunal Pleno. Questão de Ordem no Agravo de Instrumento, n. 664567. Relator: Ministro Sepúlveda Pertence. DJ 06.09.2007, p. 37. Disponível em: < www.stf.jus.br >. Acessado em: 10.02.2015.

${ }^{54}$ BRASIL. Supremo Tribunal Federal. Primeira Turma. Habeas Corpus, n. 98664. Relator: Ministro Marco Aurélio. DJe 26.03.2010, p. 55. Disponível em: <www.stf.jus.br > . Acessado em: 10.02.2015.

55 BRASIL. Supremo Tribunal Federal. Primeira Turma. Recurso em Habeas Corpus, n. 103581. Relator: Ministro Luiz Fux. DJe 02.10.2013, p. 194. Disponível em: <www.stf.jus.br > . Acessado em: 10.02.2015.
} 
o inquérito e, nesta qualidade, não lhes foi concedido o direito ao silêncio, restando, no ato, a confissão do delito. Tratava o processo do delito de falsidade ideológica, tipificado no art. 312 do Código Penal Militar (CPM), em que houve a propositura de denúncia contra cinco agentes, um como autor do falso e os outros quatro como partícipes, sendo que, durante o inquérito, estes quatro foram ouvidos como testemunhas. Narrava a denúncia que o autor fazia constar dados falsos no sistema próprio para o aumento da margem consignável, possibilitando que os partícipes contraíssem novos empréstimos em instituições financeiras mesmo com a margem original já completamente comprometida.

O voto condutor iniciou no sentido de ultrapassar a alegação de nulidade, alinhavando que eventuais irregularidades da fase inquisitorial não se comunicam ao processo penal. Seguiu-se, então a discussão entre o relator e os Min. Marco Aurélio e Cármen Lúcia sobre outro ponto do voto - em relação a outra nulidade arguida, reconhecida pelo relator e debatida pelos outros dois ministros -, o que motivou o pedido de vistas do Min. Dias Toffoli. No retorno dos autos para julgamento, o voto vista limitou-se a informar a existência de pedido de desistência do HC, que foi homologada pela Primeira Turma, à unanimidade. Contudo, a par da decisão de homologação da desistência - e consequente não conhecimento do HC - restou assim escrita a ementa do acórdão:

PROCESSUAL PENAL. RECURSO ORDINÁRIO EM HABEAS CORPUS. DIREITO PENAL E PROCESSUAL PENAL MILITAR. CRIME DE FALSIDADE IDEOLÓGICA (CPM, ART. 312). TRANCAMENTO DA DENÚNCIA. DESCABIMENTO. CONDUTAS SUFICIENTEMENTE INDIVIDUALIZADAS. SUPERVENIENTE INDICIAMENTO DE PARTES QUE PRESTARAM DEPOIMENTO COMO TESTEMUNHAS NO INQUÉRITO POLICIAL MILITAR. NULIDADE. INOCORRÊNCIA. MATÉRIA DE FATO E DE PROVA. VÍCIO NO INQUÉRITO POLICIAL. AUSÊNCIA DE CONTAMINAÇÃO DA AÇÃO PENAL. PRAZO MÍNIMO DE 24 (VINTE E QUATRO) HORAS ENTRE A CITAÇÃO E INTERROGATÓRIO. CÓDIGO DE PROCESSO PENAL MILITAR, ART. 291. PRINCÍPIOS DA AMPLA DEFESA E DO CONTRADITÓRIO (CRB, ART. 5', LV). INOBSERVÂNCIA. NULIDADE ABSOLUTA. RECURSO PARCIALMENTE PROVIDO. PEDIDO DE VISTA. SUPERVENIENTE PEDIDO DE DESISTÊNCIA. HOMOLOGAÇÃO. 1. A ação penal e o seu eventual trancamento deve ser reservado apenas para situações excepcionais, por ausência de justa causa, ou quando evidente a ilegalidade demonstrada em inequívoca prova pré-constituída, o que não se verifica na presente hipótese, em que a denúncia observou os termos do art. 77 do CPPM. Com efeito, as condutas estão suficientemente individua- 
lizadas na exordial acusatória, havendo perfeita delimitação fática a partir da qual é viável o exercício do direito de defesa, ainda que não se possa precisar o dia, hora e local exato do fato delituoso, que se revela irrelevante na presente causa. (Precedentes: RHC 103.467/RJ, Relator Min. Ricardo Lewandowski, Julgamento em 24/8/2010; RHC 93.801/SP, Relator Min. Menezes Direito, Primeira Turma, Julgamento em 25/3/2008; RHC 84.760/DF, Relator Min. Carlos Velloso, Segunda Turma, Julgamento em 19/10/2004). 2. In casu: a) os recorrentes foram denunciados por suposta participação no crime de falsidade ideológica previsto no Código Penal Militar (art. 312); b) a conduta consistiu em alterar dolosamente os dados funcionais dos recorrentes no sistema de informações do Comando da Marinha com a finalidade de permitir a margem consignável do contracheque, e lesar o erário público com o recolhimento a menos do imposto de renda, com o auxílio do funcionário responsável. 3. O indiciamento no inquérito militar não representa constrangimento ilegal pelo simples fato de as partes terem sido ouvidas na qualidade de testemunhas na fase pré-processual, porquanto o desdobramento das investigações poderiam conduzir à conclusão de que houve participação no crime. 4. A alegação de nulidade dos depoimentos prestados nessa fase, com o escopo do acolhimento, torna indispensável o revolvimento do contexto fático-probatório, expediente incabível na via estreita do writ.(HC 86.582/SP, Relator Min. Sepúlveda Pertence, Primeira Turma, Julgamento em 4/10/2005; HC 96.086/SP, Relator Min. Eros Grau, Segunda Turma, Julgamento em 3/2/2009). 5. Os vícios do inquérito policial não contaminam a ação penal, sendo certo que, no presente caso, a instrução do processo ainda está em curso, não havendo como avaliar, nesse estágio, a influência das provas produzidas na fase pré-processual em eventual condenação. (HC 84.316/ MG, Relator Min. Carlos Britto, Primeira Turma, Julgamento em 24/8/2004; AI 687.893-AgR/PR, Relator Min. Ricardo Lewandowski, Julgamento em 26/8/2008; RHC 85.286/SP, Relator Min. Joaquim Barbosa, Julgamento em 29/11/2005). 6. Os postulados da ampla defesa e do contraditório (CRB, art. $\left.5^{\circ}, \mathrm{LV}\right)$ restam violados pela inobservância do art. 291 do Código de Processo Penal Militar (Art. 291 As citações, intimações ou notificações serão sempre feitas de dia e com a antecedência de vinte e quatro horas, pelo menos, do ato a que se referirem.), configurando nulidade absoluta a citação de dois dos recorrentes no mesmo dia em que ocorreu o interrogatório. Com efeito, no processo penal comum, de acordo com a nova sistemática adotada com o advento da Lei 11.719/2008 (art. 400 e 531 do CPP), para garantir-se maior efetividade aos postulados da ampla defesa e do contraditório, o ato do interrogatório foi relegado para o final da instrução criminal, regra processual que evita situações de cerceamento de defesa, como a do presente caso. 7. In casu, ante a ausência de informação nos documentos a respeito do horário em que foi citado o recorrente, no dia anterior ao interrogatório (mandado de 
fls. 764 do Apenso III), surge dúvida se houve o cumprimento do prazo mínimo de 24 (vinte e quatro) horas a qual milita a seu favor. No presente caso, ao menos um dos recorrentes foi citado no mesmo dia do interrogatório, restando evidente o prejuízo à sua defesa. 8. Recurso parcialmente provido, tão-somente para declarar-se a nulidade dos interrogatórios dos recorrentes citados sem a obediência do lapso temporal legal, determinando-se a renovação do ato processual, prejudicadas as demais pretensões formuladas no presente recurso ordinário em habeas corpus. 9. Julgamento interrompido em razão de pedido de vista, advindo pedido de desistência que, submetido à Primeira Turma, restou homologado.

A primeira questão a se ponderar, em relação a este julgado, é que não se presta como precedente, no particular da nulidade ora tratada. Sabe-se que somente os fundamentos que levam à decisão final, a ratio decidendi, são capazes de gerar efeitos futuros. As afirmações ou opiniões lançadas que não infirmam a decisão final são meros obiter dicta, não se podendo atribuir força de precedente judicial a tais razões que sequer diante do caso concreto geraram efeitos para se chegar à conclusão da Corte. Essa é a situação do caso, ao decidir a Turma pela homologação do pedido de desistência, qualquer outro fundamento lançado anteriormente que não leve à extinção do HC por tal razão não adquiri força de precedente. Principalmente, não se manifestando a integralidade do colegiado sobre o ponto em comento, pelo final antecipado das discussões face ao pedido de desistência, fica inviabilizado reconhecer que o posicionamento da Turma é efetivamente pela superação da nulidade alegada, ainda que esta fosse o encaminhamento inicial.

A ementa reflete, tão somente, a opinião particular do próprio relator e narra a extinção da ação constitucional pela desistência apenas nas últimas palavras. O jurista que se depara com a citada ementa é levado a crer - salvo um estudo pormenorizado do inteiro teor do julgado - que esta é a posição da respectiva Turma do STF sobre o assunto e, eventualmente, outro magistrado pode utilizá-la erroneamente como precedente. Equivocadamente, neste ponto, também porque o próprio STF, em decisão diversa, em que a mesma questão foi amplamente debatida e votada por todos os Ministros, resolveu o caso em sentido oposto, reconhecendo a nulidade pelo fato da privação ao direito ao silêncio do réu ouvido como testemunha no curso do inquérito, em outro crime militar (RHC, n. 122279). ${ }^{56}$

Apresenta-se, assim, uma ementa performática. Há, é bem verdade, a 
demonstração de erudição e estudo na ementa que não se reproduz e não guarda consonância com o resultado final do julgado. É um perfeito exemplo da estrutura dual já denunciada por Rosa, no manifesto, há um "efeito estético persuasivo de semblante", contudo, no latente, mantém-se o "vazio significante" ${ }^{57}$. No caso, a ementa, que teria por finalidade resumir o conteúdo do julgamento, se transforma em coisa diversa - como se pudesse ter vida própria - desconecta com os motivos determinantes da decisão da Corte. Isso bem demonstra a falta de uma maior problematização da própria questão do julgar e a função dos precedentes no sistema jurídico. Redige-se uma ementa para demonstrar o estudo realizado que, apesar de não servir sequer para a reconstrução da tradição jurídica, dará azo para várias citações, sem, contudo, preocupar-se com a resolução, de forma autêntica, do próprio caso posto.

\section{CONCLUSÕES}

O objetivo (ou referente) do presente texto é tratar da força gravitacional dos precedentes jurisprudenciais como elementos de determinação na tomada de decisões judiciais e, também, estabelecer alguns critérios quanto à sua incidência no contexto brasileiro, mormente considerando o Novo Código de Processo Civil (NCPC).

No concernente ao primeiro aspecto da investigação, foi adotada a proposição teórica da Teoria Complexa do Direito para fins de explicitar o papel dos precedentes no sistema jurídico brasileiro, por se considerar que apresenta vantagens perante as demais proposições paradigmáticas, nos aspectos descritivo e prescritivo da Ciência Jurídica.

De acordo com tal matriz disciplinar, um precedente, em sentido amplo (latu sensu), é uma decisão sobre um determinado tema específico e que, por estar registrada em um repositório reconhecido, pode ser consultada como orientação para futuras análises de casos similares; a expressão Precedente Jurisprudencial, por sua vez, merece ser reservada especificamente para a decisão pretérita tomada pelo Poder Judiciário, que representa o âmbito estatal específico para tomada institucionalizada de decisões jurídicas; e, por fim, a categoria Jurisprudência significa o conjunto de deliberações pretéritas de algum dos órgãos do Poder Judiciário.

De acordo com os fundamentos invocados, a Jurisprudência representa

${ }_{57}$ ROSA, Alexandre Moraes da. Apresentação. In: RAMIRES, Maurício. Crítica à aplicação de precedentes no direito brasileiro. Porto Alegre: Livraria do Advogado, 2010, p. 23. 
uma das Fontes Jurídicas legítimas para sustentar a tomada de decisões jurídicas. Sem embargo, é inegável a sua importância como critério decisório, porquanto se trata de argumento decisivo para construção da Norma Jurídica resolutória de cada caso concreto. Trata-se de substrato relevante não só para anular determinadas posições jurídicas, que contrariam o posicionamento historicamente adotado pelos tribunais, mas também como parâmetro decisivo para fixar os precisos contornos de uma decisão jurídica. Mais do que isto, trata-se de critério de grande relevância para fins de fixação da coerência institucional histórica, no sentido de permitir o acompanhamento da evolução dos entendimentos dentro de um determinado sistema e, assim, evitar eventuais arbitrariedades.

Restou destacada ainda a hierarquização das Fontes Jurídicas no cenário jurídico brasileiro, de acordo com o modelo paradigmático escolhido, no sentido de que a Jurisprudência pode ser, grosso modo, situada logo abaixo dos Textos Normativos e dos Princípios Jurídicos quanto ao seu grau de eficácia, ostentando influência de grau decisivo. Porém, não se desconhece que a legislação escrita pode estabelecer grau de potência mais intenso, atribuindo-lhe caráter intransponível ou vinculante, de acordo com a forma processual e o grau de hierarquia em que é produzido o texto jurisprudencial.

Todavia, foi advertido que a destacada relevância da Jurisprudência como critério de julgamento não reside apenas em informar qual o comando pretérito adotado (dispositivo), mas sim, principalmente, em fornecer os argumentos que foram suscitados e empregados para ensejar tal deliberação (fundamentação ou motivação), pois ali residem elementos relevantes para conformação de novas decisões em circunstâncias similares. Justamente por isto, conclui-se ser recomendável que os órgãos julgadores colegiados apresentem uma organização estruturada dos argumentos que serão objeto de julgamento, para o fim de que a votação expresse exatamente quais foram acolhidos ou rejeitados no resultado final. Isto porque é problemática a conduta de membros de colegiados que apresentam fundamentação sem sopesar os argumentos expostos pelos demais integrantes do órgão de deliberação, precisamente porque impede a dialética que é o motivo da adoção da modalidade coletiva de julgamento. Como resultado de tal postura profissional, a decisão conjunta pode até ter um dispositivo único, porém sua função precípua de orientação de casos futuros, para fins de afastamento de incertezas sobre os limites da interpretação, resta severamente prejudicada.

Prosseguindo para a segunda parte deste texto, referente ao tratamento 
dado à força gravitacional da Jurisprudência pelo NCPC, cabe mencionar que exige maior respeito aos precedentes e melhor fundamentação das decisões, fazendo valer a regra constitucional respectiva.

Em grande parte, a história mostra que a regulação processual serve, sobretudo, à limitação do poder dos juízes e frente ao atual problema do decisionismo. O fato de cada juiz ser capaz de julgar com base em seu subjetivismo, faz necessária a criação de freios epistemológicos à atividade judicial, consubstanciado, no direito brasileiro, pelas regras do NCPC. São elas evoluções importantes na dogmática processual que apontam para o sentido de organicidade do Poder Judiciário, com a necessidade de adoção ou, ao menos, a necessária fundamentação diante de decisões de instâncias superiores.

É bem verdade que a comunidade jurídica não está ainda devidamente preparada para tais mudanças. Com efeito, advogados, promotores, juízes, enfim, qualquer pessoa que pratique o direito está acostumada com o sistema vigente que não espera do profissional - pelo menos na prática - a observância de um ônus argumentativo tão grande para a realização de peças processuais. Não é comum a exploração das questões fáticas dos casos precedentes, por exemplo, o que, por si só, altera substancialmente a forma de se praticar o direito atualmente.

Trabalhar com precedentes exige do intérprete algo muito além da leitura e citação de ementas. Para se extrair a ratio decidendi e estabelecer analogia e distinções, o jurista necessita analisar as circunstâncias particulares do caso paradigma, além de toda a argumentação jurídica do Tribunal pontos de convergência dos possíveis votos. A partir de então, voltar-se ao caso em mão e igualmente analisá-lo em profundidade, observando o acerto da replicação da tese (bolding) aplicada no precedente. Estas categorias essenciais (stare decisis, analogia, distinção, superação, ratio decidendi e obter dicta) não excluem outros instrumentos úteis no exercício de fundamentar com base em precedentes. Contudo, constituem o fundamento para o necessário repensar a prática jurídica, fixando novos critérios sobre a forma de aplicação dos precedentes jurisprudenciais na ordem jurídica nacional, sobretudo a partir da vigência do NCPC.

\section{REFERÊNCIAS}

ADAMS, Maurice. The rhetoric of precedent and comparative legal research, Modern Law Review, n. 62, v. 3, p. 264-267, 1999. 
ALEXANDER, Larry. Constrained by Precedent, South California Law Review, v. 63, p. 1-64, 1989.

BRASIL. Supremo Tribunal Federal. Primeira Turma. Habeas Corpus, n. 98664. Relator: Ministro Marco Aurélio. DJe 26.03.2010, p. 55. Disponível em: <www.stf. jus.br > . Acessado em: 10.02.2015.

BRASIL. Supremo Tribunal Federal. Primeira Turma. Habeas Corpus, n. 117871. Relatora: Ministra Rosa Weber. DJe 01.07.2015, p. 128. Disponível em: <www.stf. jus.br > . Acessado em: 10.02.2015.

BRASIL. Supremo Tribunal Federal. Primeira Turma. Recurso em Habeas Corpus, n. 103581. Relator: Ministro Luiz Fux. DJe 02.10.2013, p. 194. Disponível em: $<$ www.stf.jus.br $>$. Acessado em: 10.02.2015.

BRASIL. Supremo Tribunal Federal. Segunda Turma. Recurso em Habeas Corpus, n. 83008. Relator: Ministro Maurício Corrêa. DJ 27.06.2006, p. 5. Disponível em: $<$ www.stf.jus.br $>$. Acessado em: 10.02.2015.

BRASIL. Supremo Tribunal Federal. Segunda Turma. Recurso em Habeas Corpus, n. 122279. Relator: Ministro Gilmar Mesdes. DJe 29.10.2014, p. 213. Disponível em: <www.stf.jus.br > . Acessado em: 10.02.2015.

BRASIL. Supremo Tribunal Federal. Tribunal Pleno. Ação Penal, n. 470. Relator: Ministro Joaquim Barbosa. DJe 08.10.2010, p. 190. Disponível em: <www.stf.jus. br $>$. Acessado em: 10.02.2015.

BRASIL. Supremo Tribunal Federal. Tribunal Pleno. Agravo Regimental (segundo) em Ação Penal, n. 470. Relator: Ministro Joaquim Barbosa. DJe 03.03.2009, p. 79. Disponível em: <www.stf.jus.br > Acessado em: 10.02.2015.

BRASIL. Supremo Tribunal Federal. Tribunal Pleno. Questão de Ordem no Agravo de Instrumento, n. 664567. Relator: Ministro Sepúlveda Pertence. DJ 06.09.2007, p. 37. Disponível em: <www.stf.jus.br > Acessado em: 10.02.2015.

BRASIL. Supremo Tribunal Federal. Tribunal Pleno. Recurso em Habeas Corpus, n. 83181. Relator para o acórdão: Ministro Joaquim Barbosa. DJ 22.10.2004, p. 5. Disponível em: <www.stf.jus.br > Acessado em: 10.02.2015. 
DIMOULIS, Dimitri. Manual de Introdução ao estudo do direito. 4 ed. São Paulo: RT, 2011.

DWORKIN, Ronald. 0 império do direito. 2 ed. Tradução: Jefferson Luiz Camargo. São Paulo: Martins Fontes, 2007.

DWORKIN, Ronald. Uma questão de princípio. 2 ed. São Paulo: Martins Fontes, 2005.

ESTADOS UNIDOS DA AMÉRICA. Brown v Board of Education. U.S. Report, v. 347, p. 483,1954 .

ESTADOS UNIDOS DA AMÉRICA. Patterson v. McLean Credit Union. U.S. Report, v. 491, p. $173-174,1989$.

ESTADOS UNIDOS DA AMÉRICA. Plessy v. Ferguson. U.S. Report, v. 163, p. 537, 1896.

FLETCHER, George P.; SHEPPARD, Steve. American Law: in a global context. Oxford University Press: Nova Iorque, 2005.

GARNER, Bryan A. (Org.). Black's law dictionary. 9. ed. St. Paul: West Publishing, 2009.

GERHARDT, Michael J. The role of precedent in constitutional decision-making and theory. George Washington Law Review, v. 60. p. 68-159, 1991.

LAMY, Eduardo de Avelar; LUIZ, Fernando Vieira. Contra o aspecto prospectivo do precedente: uma crítica hermenêutica a Frederick Schauer. Revista de Processo, v. 250, a. 40, p. 383-402. São Paulo: RT, dez. 2015.

LANGENBUCHER, Katja. Argument by analogy in the european law. Cambridge Law Journal, v. 57, p. 481, 1998.

LEVI, Edward H. An Introduction to Legal Reasoning. Chicago: The University of Chicago Press, 1970.

LUIZ, Fernando Vieira. Teoria da decisão judicial: dos paradígmas de Ricardo 
Lorenzetti à resposta adequada à Constituição de Lenio Streck. Porto Alegre: Livraria do Advogado, 2013.

MARINONI, Luiz Guilherme. Precedentes obrigatórios. 3 ed. São Paulo: RT, 2013.

NELSON, Caleb. Stare decisis and demonstrably erroneous precedents, Virginia Law Review, v. 87, n. 1, p. 1-84, mar. 2002.

NEUMANN JR., Richard K. Legal reasoning and legal writing: structure, strategy, and style. 5 ed. Aspen: Nova Iorque, 2005.

NEVES, Marcelo. Entre Hidra e Hércules: princípios e regras constitucionais como diferença paradoxal do sistema jurídico. 2 ed. São Paulo: Martins Fontes, 2014.

PASOLD, César. Metodologia da pesquisa jurídica: Teoria e prática. 12 ed. São Paulo: Conceito, 2011.

RE, Edward D. Stare decisis. Revista de processo, v. 19, n. 73, p. 47-54, São Paulo: RT, jan./mar., 1994.

ROSA, Alexandre Moraes da. Apresentação. In: RAMIRES, Maurício. Crítica à aplicação de precedentes no direito brasileiro. Porto Alegre: Livraria do Advogado, 2010.

SOUZA, Marcelo Alves Dias de. Do precedente judicial à súmula vinculante. Curitiba: Juruá, 2006.

STRECK, Lenio Luiz; ABBOUD, Georges. O que é isto: o precedente judicial e as súmulas vinculantes? 3 ed. Porto Alegre: Livraria do Advogado, 2015.

STRECK, Lenio Luiz; ABBOUD, Georges. Súmulas no direito brasileiro: eficácia, poder e função. Porto Alegre: Livraria do Advogado, 1998.

STRECK, Lenio Luiz; ABBOUD, Georges. Verdade e consenso: constituição, hermenêutica e teorias discursivas. 4 ed. São Paulo: Saraiva, 2011.

SUNSTEIN, Cass. R. Legal Reasoning and Political Conflict. Nova Iorque: Oxford University Press, 1996 
TUCCI, José Rogério Cruz e. Precedente judicial como fonte do direito. São Paulo: RT, 2004.

VOJVODIC, Adriana de Moraes; MACHADO, Ana Mara França; CARDOSO, Evorah Lusci Costa. Escrevendo um romance, primeiro capítulo: precedentes e processo decisório no STF. Revista Direito GV, v. 5, p. 36, jan.-jun. 2009.

WARAT, Luís Alberto. Mitos e teorias na interpretação da lei. Porto Alegre: Síntese, 1979.

ZANON JUNIOR, Orlando Luiz. Produção jurídica: positivação e aplicação. Âmbito Jurídico, n. 112, Rio Grande, Disponível em <www.ambito-juridico.com.br > . Acesso em 21.09.2015.

ZANON JUNIOR, Orlando Luiz. Teoria complexa do direito. 2 ed. Curitiba: Prismas, 2015.

Recebido em: 17 de fevereiro de 2016 Aceito em: 29 de junbo de 2016 